CZASOPISMO INŻYNIERII LACDOWEJ, ŚRODOWISKA I ARCHITEKTURY JOURNAL OF CIVIL ENGINEERING, ENVIRONMENT AND ARCHITECTURE

JCEEA, t. XXX, z. 60 (1/13), styczeń-marzec 2013, s. 175-184

Grzegorz STRA $\dot{Z}^{1}$

\title{
LABORATORY INVESTIGATION OF STRAIN PROPERTIES ON PEAT FROM RZESZÓW AREA
}

\begin{abstract}
Laboratory tests of strain properties on a selected peat from Rzeszow. Sampling methods for soil of undisturbed structure and methodology of oedometric tests. These tests were carried out under procedures set by Polish standards, using for this purpose a set of oedometers with an automatic system of data acquisition GEOLAB. The oedometric tests conducted on peat samples in a possibly wide range permitted, on the basis of obtained average values, to develop curves of: primary loading, unloading and reloading. These curves show strain properties of the tested soil under an applied load. The specific values of oedometric moduli of primary loading, unloading and reloading obtained from own tests were subjected to an elementary statistical analysis. Due to a potential heterogeneity of the tested peat, the values of coefficients of variation were also determined with regard to a specific range of vertical stresses. While analysing tests results, it was noticed that the deformation of peat, exposed to a load that causes the highest primary loading, makes up to $40 \%$ against the primary height of the sample. After an unloading process was carried out according to standard guidelines and after the reloading process with identical loads took place, it turned out that an average deformation caused by the highest secondary stress increase not exceed $3 \%$ of primary strains. A conclusion can be drawn that if there is a need for improvement of this type of soil for construction purposes, they must undergo consolidation.
\end{abstract}

Keywords: peat, organic soil, oedometric modulus of primary loading, oedometric modulus of reloading, oedometric modulus of unloading

\section{Introduction}

A complex structure, large heterogeneity, lithological variability and above all insufficient investigation result, despite all our efforts, in organic soils, especially peats, being classified as soft soils. Specific properties, i.e. a very high compression and low shear strength in regards to mineral soils cause that they are regarded to be totally void of bearing capacity. It translates to the fact that foundation engineering on organic soil subsoil culminate, as a rule, in a expen-

\footnotetext{
${ }^{1}$ Autor do korespondencji: Grzegorz Straż, Rzeszow University of Technology, 2 Poznanska Street, 35-084 Rzeszow, tel. +48 17 8651006, gstraz@prz.edu.pl.
} 
sive deep foundation or a change into bearing soils in a case of shallow foundations.

There are also cases where it is necessary to locate investments that do not require special precautions, e.g. storage areas, small depots on soft soil sites, including peats, in form of interbeddings of a relatively low thickness at a depth which do not exceed the active zone, but deeply enough that soil replacement is unprofitable, not to mention the deep foundation. Then, according to the author, it can be attempted to think through a possibility of using the local organic soils as a part of foundation soil, whereas the knowledge of their geotechnical parameters, in particular the way of behaviour under a specific load, is the priority, which decides about their usefulness and has a direct influence on the reduction of investment costs. Of course, one should be aware of the fact that the possible settlements will be much bigger than in case of typical foundation soils.

The following study presents the results of laboratory tests on peat from Rzeszów and aims to determine strain properties of soil under an applied load. These tests were carried out under procedures set by Polish standards [1], using for this purpose a set of oedometers with an automatic system of data acquisition GEOLAB. The undertaken task proved to be exceptionally strenuous and timeconsuming, especially because of the nature of the tested centre, since peats are organic soils containing organic components above 30\%. They are mostly formed from dead parts of plants and undergo a gradual carbonization $[2,3]$. The PN-EN ISO [4] code, which was introduced in 2006 in Poland, has modified the present classification of organic soils and peats have been classified as high organic soils, i.e. containing organic matter above $20 \%$.

\section{Soil under investigation}

The investigation on ground and water conditions was performed on a military training area located in the south-eastern part of the city of Rzeszów by making ten boreholes for this aim. On the basis of the boreholes, a layer of peat was detected of a changeable thickness, occurring at a depth from $0,9 \mathrm{~m}$ to 7,5 $\mathrm{m}$ b.g.l. in the immediate neighbourhood of organic soils and muds. It was also noticed that the water table is situated very near the ground surface and as it turned out in the course of time it is highly susceptible to precipitations. This was concluded from considerable level variations seen in the well on this military area. Thus, even after a short, but heavy, rain shower the local water table level went above the soil horizon causing some local flooding [5, 6].

After analysing the geotechnical investigation performed on soil samples taken from the boreholes, it was assumed that the representative depth for the sampled peat, i.e. allowing to take samples with properties as similar as possible, is the depth $1,35 \mathrm{~m} \mathrm{b.g.l}$. From this depth, there were taken peat undisturbed samples for laboratory tests. It should be pointed out that obtaining high quality of undisturbed samples for oedometric tests in such complex ground and water 
conditions was the most difficult and the most time-consuming stage of the research $[7,8]$.

Laboratory tests of the collected peat were started from marking its degree of decomposition which allowed its precise classification. This was achieved in a macroscopic way by comparing the behaviour of plant residues, the plastic and structural properties, the colour of the peat and the colour of water squeezed from the peat and eventually the smears that were made. It was noticed that the degree of peat decomposition is included within the range $50-60 \%$ which corresponds to $\mathrm{H}_{6}$ group according to van Post scale [2], the most common scale in Geotechnical Engineering, and to the table developed by Maciak and Liwski with additional features [9]. Moreover, further markings showed that the tested peat of an average water content amounting to about $290 \%$ and density of soil amounting to about $1,10 \mathrm{~g} / \mathrm{cm}^{3}$ includes about $75 \%$ of organic matters. The average value of the liquidity index amounted to 0,5 which allowed to classify the tested peat as a soil on the verge of plastic and slightly-plastic. The peat water $\mathrm{pH}$ was identified with a calorimetric method, using an indicator paper and was estimated at around $6 \mathrm{pH}$.

The oedometric tests of strain properties of the selected peat from Rzeszów were carried out on 23 carefully selected of undisturbed samples. These samples had a diameter of $65 \mathrm{~mm}$ and a height of $20 \mathrm{~mm}$ and were optimally protected from moisture loss, both during the transportation, the storage, as well as during the tests.

\section{Investigation methodology}

The attempts aiming at determining the deformation of the tested peat were made under laboratory conditions by means of a set of oedometers and under the following assumptions:

1. The tests were carried out exclusively on peat of undisturbed samples which were put into steel testers from a depth of about $1,35 \mathrm{~m} \mathrm{b.g.l.}$

2. The specimens of undisturbed structure dedicated for testing had a standard size: a diameter of $65 \mathrm{~mm}$ and a height of $20 \mathrm{~mm}$.

3. All these samples were tested in oedometers with an automatic system of data acquisition GEOLAB under the same conditions and by applying identical testing parameters.

4. In general, 23 full test cycles were carried out. Their results involve the determination of the values of oedometric moduli of primary loading, unloading and reloading.

5. After the highest load predicted had been applied and the settlements stabilised, the samples were unloaded and then reloaded according to standard guidelines [1]. 
6. The load in oedometers was applied within the range that causes vertical stresses from 0 to $400 \mathrm{kPa}$, and the next degrees differed by $12,5 \mathrm{kPa}$, $25 \mathrm{kPa}, 50 \mathrm{kPa}, 100 \mathrm{kPa}$ and $200 \mathrm{kPa}$.

7. The specimens were not exposed to primary consolidation before testing.

\section{Tests results}

A high organic matters in the tested peat caused that it can be characterised by an extremely large compressibility in comparison to mineral soils. As a result of this, the determination of its strain properties proved to be very difficult. The main reason for these difficulties was connected with incomparably longer periods, essential for the stabilization of the settlements of these samples. This stabilization was, in turn, necessary for further tests, applying another specific load values.

The oedometric tests conducted on peat samples in a possibly wide range permitted, on the basis of obtained average values, to develop curves of: primary loading (C.P.L.), unloading (C.U.) and reloading (C.R.). These curves show strain properties of the tested soil under an applied load. These properties are presented on Fig. 1.

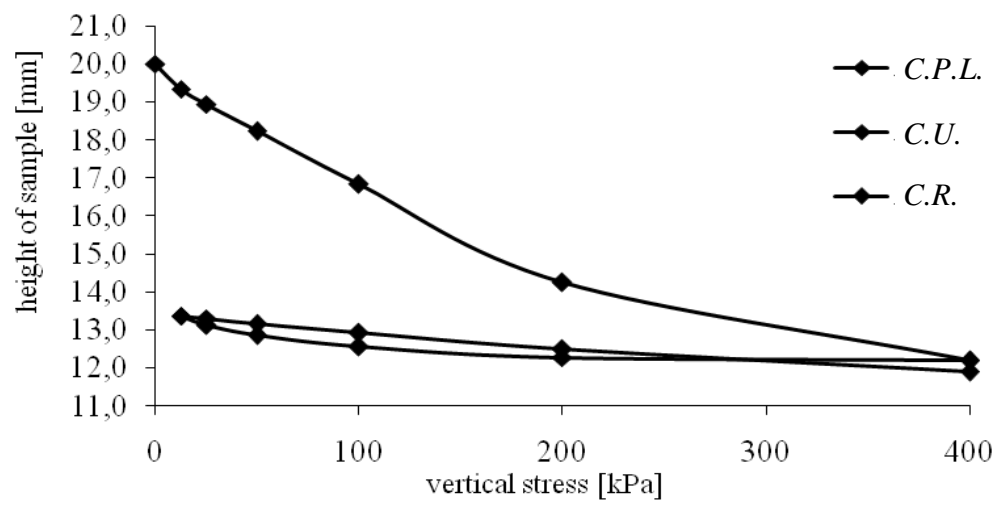

Fig. 1. Curves of primary loading, unloading and reloading for samples of peat plotted on the basis of average values

Rys. 1. Krzywe ściśliwości pierwotnej, odprężenia i wtórnej wykreślone na podstawie wartości średnich

The specific values of oedometric moduli of primary loading, unloading and reloading obtained from own tests were subjected to an elementary statistical analysis. Due to a potential heterogeneity of the tested peat, the values of coefficients of variation were also determined with regard to a specific range of vertical stresses. The results of the conducted tests and calculations are listed, in detail, in the tables (Tables 1-3). 
Table 1 . The values of oedometric moduli of primary loading specified for the tested peat

Tabela 1. Wartości edometrycznych modułów ściśliwości pierwotnej określone dla badanego torfu

\begin{tabular}{|c|c|c|c|c|c|}
\hline \multirow{2}{*}{$\begin{array}{l}\text { Change of the } \\
\text { vertical stress } \\
\text { acting on the } \\
\text { sample } \sigma[\mathrm{kPa}]\end{array}$} & \multirow{2}{*}{$\begin{array}{c}\text { Vertical } \\
\text { stress } \\
\text { increase } \\
\Delta \sigma[\mathrm{kPa}]\end{array}$} & \multicolumn{3}{|c|}{$\begin{array}{l}\text { The values of oedometric modulus } \\
\text { of primary loading } E_{\text {oed } L}[\mathrm{kPa}]\end{array}$} & \multirow{2}{*}{ 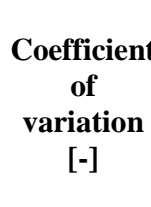 } \\
\hline & & $\begin{array}{l}\text { the range } \\
\text { of values }\end{array}$ & $\begin{array}{c}\text { the } \\
\text { average } \\
\text { value }\end{array}$ & $\begin{array}{c}\text { the standard } \\
\text { deviation }\end{array}$ & \\
\hline $0-12,5$ & 12,5 & $255,10-675,68$ & 398,62 & 100,25 & 0,25 \\
\hline $12,5-25$ & 12,5 & $459,91-805,00$ & 599,24 & 78,74 & 0,13 \\
\hline $25-50$ & 25 & $444,76-1086,05$ & 634,25 & 95,84 & 0,15 \\
\hline $50-100$ & 50 & $397,07-2563,89$ & 673,38 & 139,63 & 0,21 \\
\hline $100-200$ & 100 & $491,85-992,90$ & 735,99 & 120,23 & 0,16 \\
\hline $200-400$ & 200 & $892,73-2262,60$ & 1323,32 & 371,72 & 0,28 \\
\hline
\end{tabular}

Table 2. The values of oedometric moduli of unloading specified for the tested peat

Tabela 2. Wartości edometrycznych modułów odprężenia określone dla badanego torfu

\begin{tabular}{|c|c|c|c|c|c|}
\hline \multirow{2}{*}{$\begin{array}{c}\text { Change of the } \\
\text { vertical stress } \\
\text { acting on the } \\
\text { sample } \sigma[\mathrm{kPa}]\end{array}$} & \multirow{2}{*}{$\begin{array}{c}\text { Vertical } \\
\text { stress } \\
\text { increase } \\
\Delta \sigma[\mathrm{kPa}]\end{array}$} & \multicolumn{3}{|c|}{$\begin{array}{l}\text { The values of oedometric modulus } \\
\text { of unloading } E_{\text {oed } U}[\mathrm{kPa}]\end{array}$} & \multirow{2}{*}{$\begin{array}{c}\text { Coefficient } \\
\text { of } \\
\text { variation } \\
{[-]}\end{array}$} \\
\hline & & $\begin{array}{l}\text { the range } \\
\text { of values }\end{array}$ & $\begin{array}{c}\text { the } \\
\text { average } \\
\text { value } \\
\end{array}$ & $\begin{array}{c}\text { the } \\
\text { standard } \\
\text { deviation }\end{array}$ & \\
\hline $400-200$ & 200 & $7154,29-20083,33$ & 14654,87 & 5189,63 & 0,35 \\
\hline $200-100$ & 100 & $2775,00-7872,22$ & 4753,77 & 1470,17 & 0,31 \\
\hline $100-50$ & 50 & $1784,38-2585,42$ & 2208,91 & 247,68 & 0,11 \\
\hline $50-25$ & 25 & 757,05-2020,59 & 1363,68 & 462,59 & 0,34 \\
\hline $25-12,5$ & 12,5 & $276,12-1701,25$ & 772,83 & 485,71 & 0,63 \\
\hline
\end{tabular}

Table 3. The values of oedometric moduli of reloading specified for the test peat

Tabela 3. Wartości edometrycznych modułów ściśliwości wtórnej określone dla badanego torfu

\begin{tabular}{|c|c|c|c|c|c|}
\hline \multirow{2}{*}{$\begin{array}{c}\text { Change of the } \\
\text { vertical stress }\end{array}$} & \multirow{2}{*}{$\begin{array}{c}\text { Vertical } \\
\text { stress } \\
\text { acting on the } \\
\text { increase }\end{array}$} & \multicolumn{2}{|c|}{$\begin{array}{c}\text { The values of oedometric modulus } \\
\text { of reloading } \mathbf{E}_{\text {oed } \mathbf{R}}[\mathbf{k P a}]\end{array}$} & \multirow{2}{*}{$\begin{array}{c}\text { Coefficient } \\
\text { of } \\
\text { sample } \boldsymbol{\sigma}[\mathbf{k P a}]\end{array}$} & $\begin{array}{c}\Delta \boldsymbol{\sigma}[\mathrm{kPa}] \\
\text { variation } \\
{[-]}\end{array}$ \\
\hline $12,5-25$ & 12,5 & $1534,09-2301,79$ & $\mathbf{1 8 7 2 , 7 7}$ & 249,92 & 0,13 \\
\hline $25-50$ & 25 & $1544,32-3561,11$ & $\mathbf{2 1 1 5 , 3 2}$ & 637,66 & 0,30 \\
\hline $50-100$ & 50 & $1500,00-7956,25$ & $\mathbf{3 1 2 5 , 3 1}$ & 1467,02 & 0,47 \\
\hline $100-200$ & 100 & $2505,77-4209,68$ & $\mathbf{3 3 2 3 , 7 6}$ & 425,54 & 0,13 \\
\hline $200-400$ & 200 & $2288,89-7470,59$ & $\mathbf{4 0 4 3 , 2 6}$ & 1719,67 & 0,43 \\
\hline
\end{tabular}


After analysing the test results shown in Tables, an attempt was made to specify the correlation between empirically obtained values of an oedometric modulus of primary loading (Fig. 2), an oedometric modulus of unloading (Fig. 3 ) and an oedometric modulus of reloading (Fig. 4) for the tested peat and the vertical stress increase.

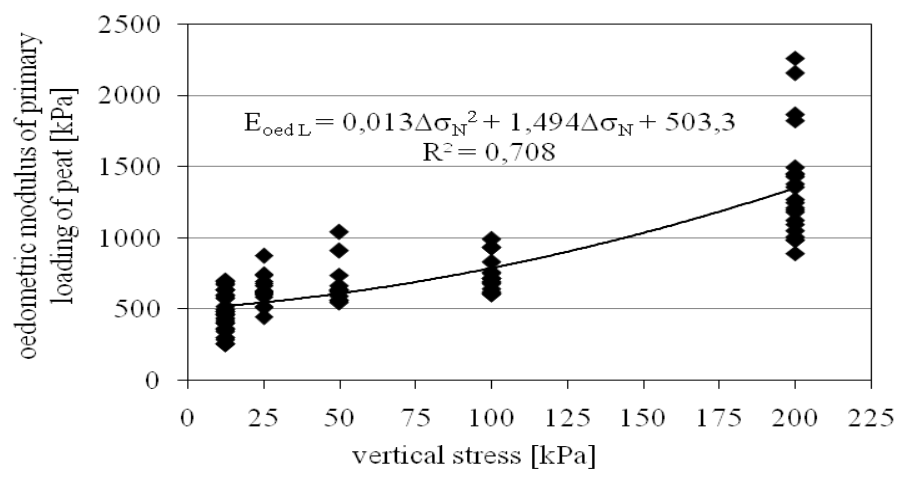

Fig. 2. An example of relationship between values of an oedometric modulus of primary loading and the vertical stress increase

Rys. 2. Przykład zależności pomiędzy wartościami edometrycznych modułów ściśliwości pierwotnej badanego torfu od przyrostu naprężeń normalnych

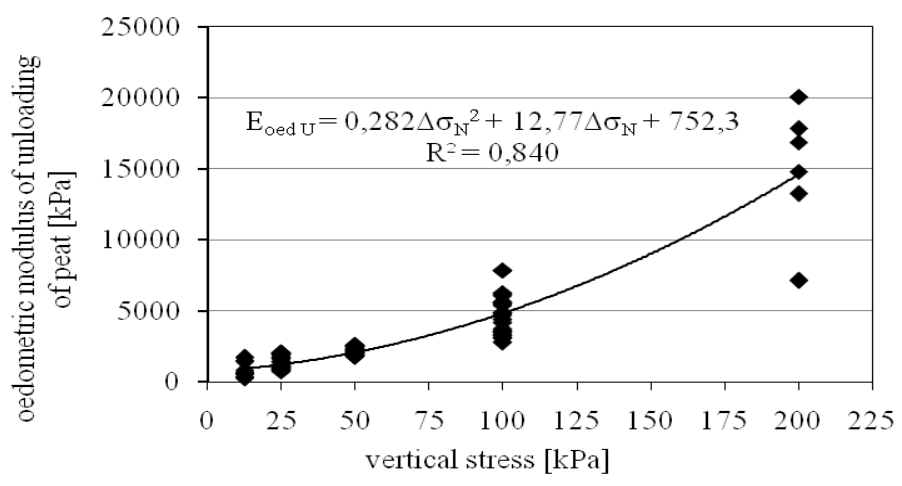

Fig. 3. Relationship between an oedometric modulus of unloading of peat and the vertical stress increase

Rys. 3. Przykład zależności pomiędzy wartościami edometrycznych modułów odprężenia badanego torfu od przyrostu naprężeń normalnych

The correlation shown on Fig. 2 between empirically obtained values of an oedometric modulus of primary loading and the vertical stress increase was described with a specific formula: 


$$
\mathrm{E}_{\text {oedL }}=0,0138 \Delta \sigma_{\mathrm{N}}^{2}+1,4941 \Delta \sigma_{\mathrm{N}}+503,36
$$

where: $\mathrm{E}_{\mathrm{eod} \mathrm{L}}$ - oedometric modulus of primary loading,

$\Delta \sigma_{\mathrm{N}}-$ vertical stress increase.

The relationship between empirically determined values of oedometric moduli of unloading of the peat from Rzeszów and the vertical stress increase was presented on Fig. 3 and described with the following formula:

$$
\mathrm{E}_{\text {oedU }}=0,2852 \Delta \sigma_{\mathrm{N}}^{2}+12,774 \Delta \sigma_{\mathrm{N}}+752,32
$$

where: $\mathrm{E}_{\mathrm{eod} \mathrm{S}}$ - oedometric modulus of unloading, $\Delta \sigma_{\mathrm{N}}-$ vertical stress increase.

The relationship between the values of oedometric moduli of reloading and the vertical stress increase, determined in own tests, was presented on Fig. 4 and described with a formula:

$$
\mathrm{E}_{\text {eodR }}=-0,0603 \Delta \sigma_{\mathrm{N}}^{2}+24,131 \Delta \sigma_{\mathrm{N}}+1615,1
$$

where: $\mathrm{E}_{\mathrm{eod} \mathrm{R}}-$ oedometric modulus of reloading, $\Delta \sigma_{\mathrm{N}}-$ vertical stress increase.

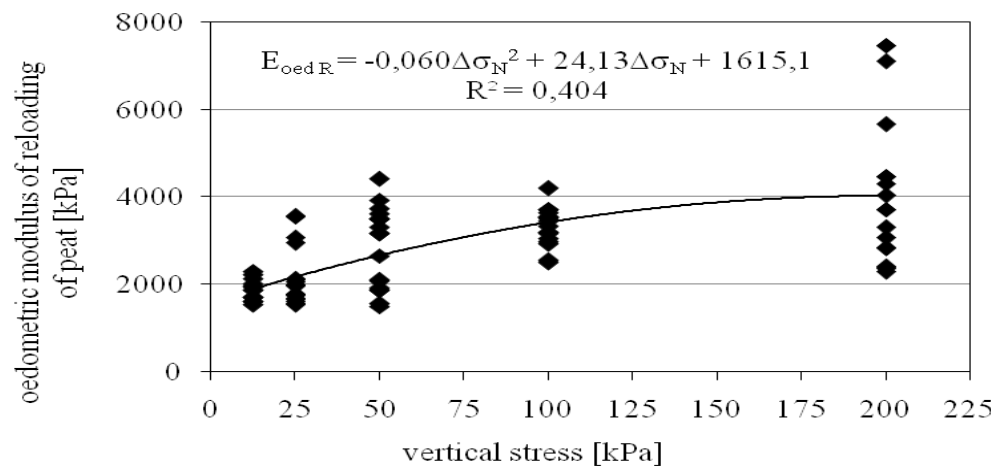

Fig. 4. Relationship between an oedometric modulus of reloading of peat and the vertical stress increase

Rys. 4. Przykład zależności pomiędzy wartościami edometrycznych modułów ściśliwości wtórnej badanego torfu od przyrostu naprężeń normalnych

\section{Closing remarks}

The values of oedometric moduli of primary loading, unloading and reloading, determined in own tests, are considered valid because they are supported by tests of other scientists [2, 10-16]. While analysing tests results 
(Fig. 1), it was noticed that the deformation of peat, exposed to a load that causes the highest primary loading (400 kPa), makes up up to $40 \%$ against the primary height of the sample. After an unloading process was carried out according to standard guidelines [1] and after the reloading process with identical loads took place, it turned out that an average deformation caused by the highest secondary stress increase does not exceed 3\% of primary strains. A conclusion can be drawn that if there is a need for improvement of this type of soil for construction purposes, they must undergo consolidation. Of course, this can happen only in cases where there is no possibility of soil replacing and the peat itself occurs in form of regular interbeddings with an approximate and rather small water content. The efforts aiming at improving the properties of a peat through dynamic compaction have been undertaken and published by the author [17]. The relationships determined on the basis of the conducted tests (1)(3) can be relevant for calculating the potential settlements of this substratum containing interbeddings of the analysed peat. It must be borne in mind that organic soils, including peats, are centres of incredibly high nonhomogeneity, which is confirmed by the values of the obtained coefficients of variation (Tables 1-3). Furthermore, organic soils depending on the actual ground and water conditions undergo a number of destructive processes, for example mineralisation or secondary humification [18]. These processes directly influence their geotechnical parameters which must be measured very carefully [19].

\section{References}

1. PN-88/B-04481: Grunty budowlane. Badania próbek gruntu.

2. Myślińska E.: Grunty organiczne i laboratoryjne metody ich badania. Wydawnictwo Naukowe PWN, Warszawa 2001.

3. PN-86/B-02480: Grunty budowlane. Określenia, symbole, podział i opis gruntów.

4. PN-EN ISO 14688-2: Badania geotechniczne. Oznaczanie i klasyfikowanie gruntów. Część 2: Zasady klasyfikowania. PKN, Warszawa 2006.

5. Straż G.: Badania parametrów geotechnicznych organicznych gruntów Podkarpacia. Politechnika Rzeszowska, Rzeszów 2009 (praca niepublikowana).

6. Straż G.: Parametry wytrzymałościowe rzeszowskich namułów i torfów. Oficyna Wydawnicza Politechniki Rzeszowskiej, Rzeszów 2011.

7. Straż G.: $\mathrm{O}$ awarii budynku mieszkalnego posadowionego na podłożu $\mathrm{z}$ gruntów organicznych w Rzeszowie. Zeszyty Naukowe Politechniki Rzeszowskiej, Seria: Budownictwo i Inżynieria Środowiska, 262, 51, 2009, 107-116.

8. Straż G.: O niektórych problemach związanych z określaniem parametrów geotechnicznych rzeszowskich gruntów organicznych, [w:] J. Bzówka, Badania i analizy wybranych zagadnień z budownictwa. Wydawnictwo Politechniki Śląskiej, Gliwice 2011.

9. Maciak F., Liwski S.: Ćwiczenia z torfoznawstwa. Wydawnictwo SGGW, Warszawa 1996. 
10. Jaremski J.: Parametry geotechniczne niektórych gruntów występujących na obszarze województwa podkarpackiego. XIII Krajowa Konferencja Mechaniki Gruntów i Fundamentowania. Zeszyty Naukowe Politechniki Śląskiej, 97, 2003, 421-430.

11. Jaremski J.: Przyczyny powstawania niszczących odkształceń podłoża obiektów stacji paliw w Radymnie. XI International Scientific Conference „Lviv-Koszyce-Rzeszów". Politechnika Lwowska, Lwów 2007, 380-385.

12. Krok R., Meyer Z.: Interpretacja badań edometrycznych torfu. Inżynieria Morska i Geotechnika, 2/1994, 69.

13. Molisz R., Werno M., Baran L.: Budowa nasypu drogowego na torfie. Drogownictwo, 1, 1978, 21-23.

14. Molisz R., Werno M., Baran L.: Posadawianie nasypów na gruntach organicznych metodą wstępnej konsolidacji. Wydawnictwa Komunikacji i Łączności, Warszawa 1981.

15. Pisarczyk S.: Grunty nasypowe. Właściwości geotechniczne i metody ich badania. Oficyna Wydawnicza Politechniki Warszawskiej, Warszawa 2004.

16. Zadroga B., Damicz J., Werno M.: Osiadanie i konsolidacja gruntów organicznych obciążonych nasypami ziemnymi. Inżynieria Morska i Geotechnika, 1/2003, 21-29.

17. Straż G.: Badanie własności próbek preparowanych na bazie torfu naturalnego poddanych zagęszczeniu dynamicznemu. Inżynieria Morska i Geotechnika, 5, 2011, 413-418.

18. Olchawa A.: Właściwości gruntowych kompozytów jako materiału do budowy obwałowań przeciwpowodziowych. Wydawnictwo IMUZ, Falenty 2003.

19. PN-EN 1997-2:2007: Eurokod 7. Projektowanie geotechniczne. Część 2. Rozpoznanie i badanie podłoża gruntowego.

\section{BADANIA LABORATORYJNE WLAŚCIWOŚCI ODKSZTALCENIOWYCH GRUNTU ORGANICZNEGO NA PRZYKLADZIE TORFU Z RZESZOWA}

\section{Streszczenie}

W pracy przedstawiono rezultaty badań mających na celu określenie właściwości odkształceniowych lokalnie występującego gruntu organicznego - torfu, który po obciążeniu charakteryzował się wyjątkowo wysoką odkształcalnością w porównaniu z typowymi gruntami budowlanymi. Zaprezentowano sposób pozyskania próbek o nienaruszonej strukturze badanego gruntu, wyniki oznaczeń podstawowych cech fizycznych oraz przyjętą metodykę dalszych badań Zasadniczą ich część przeprowadzono w warunkach laboratoryjnych, wykorzystując w tym celu zestaw edometrów sprzężony $\mathrm{z}$ systemem automatycznego gromadzenia danych GEOLAB. Obciążenia zadawano w zakresie wywołującym naprężenia normalne od 0 do $400 \mathrm{kPa}$, stopniując o 12,$5 ; 25 ; 50 ; 100$ oraz $200 \mathrm{kPa}$. Opracowano krzywe ściśliwości pierwotnej, odprężenia i ściśliwości wtórnej, na których podstawie obliczono wartości edometrycznych modułów ściśliwości pierwotnej, odprężenia i ściśliwości wtórnej poddanych podstawowej analizie statystycznej. Otrzymane wyniki przeanalizowano w aspekcie zadawanego naprężenia oraz znaleziono korelacje adekwatne do rozpatrywanych sytuacji. Ze względu na potencjalną niejednorodność badanego torfu, określono również wartości współczynników zmienności w odniesieniu do konkretnych zakresów naprężeń normalnych. Ustalone na podstawie badań 
własnych właściwości edometrycznych modułów ściśliwości pierwotnej, wtórnej i odprężenia rzeszowskiego torfu znalazły potwierdzenie w pracach innych badaczy [2, 10-16], uznano je więc za prawidłowe. Analizując wyniki badań, zaobserwowano, że odkształcenie torfu poddanego obciążeniu wywołującemu maksymalne naprężenie pierwotne stanowi aż $40 \% \mathrm{w}$ stosunku do początkowej wysokości próbki. Po przeprowadzeniu procesu odciążania i obciążeniu wtórnym torfu wykazano, że średnie odkształcenie próbek spowodowane maksymalnym przyrostem naprężeń wtórnych nie przekracza 3\% odkształceń pierwotnych. Nasuwa się wniosek, że jeżeli w szczególnych przypadkach zachodzi potrzeba ulepszenia tego typu gruntów do celów budowlanych, to należy je poddać konsolidacji.

Słowa kluczowe: torf, grunt organiczny, edometryczny moduł ściśliwości pierwotnej, edometryczny moduł ściśliwości odprężenia, edometryczny moduł ściśliwości wtórnej

DOI: $10.7862 / \mathrm{rb} .2013 .13$

Przesłano do redakcji w marcu $2013 \mathrm{r}$.

Przyjęto do druku w czerwcu 2013 r. 